\title{
EDITORIAL
}

\section{Multi-Drug Resistant Urinary Tract Infection: An Emerging Health Issue}

\author{
MA RAHIMa ${ }^{\mathrm{a}}$ M MOSTAFI ${ }^{\mathrm{b}}$
}

Urinary tract infection (UTI) is the most common bacterial infection among adults throughout the world, with an estimated annual global incidence of 150-250 million cases. ${ }^{1,2}$ Females of child bearing age constitute the most commonly affected group; while patients with diabetes mellitus (DM) are also at increased risk for UTI. $^{3}$ Enteric Gram-negative organisms are the predominant infective agents responsible for UTI with Escherichia coli being at the top of the list and is responsible for $60-90 \%$ cases in different series followed by Klebsiella pneumonia. $^{3-5}$

Antimicrobials are the main weapons to treat UTI. The Infectious Diseases Society of America (IDSA) recommended using empiric antibiotics in uncomplicated cystitis ${ }^{6}$ and such cases merit no investigation. However, an enormous numbers of papers from every corner of the globe described high levels of drug resistance in community acquired UTI and Bangladesh is not an exception..$^{3-5}$ In Bangladesh, over $90 \%$ UTI cases are reported as having resistance to commonly prescribed antibiotics for UTI including fluoroquinolones, penicillins and oral cephalosporins. $^{3,5}$ Most fluoroquinolone resistant organisms from urinary isolates were fulfilling the criteria for multi-drug resistance (MDR). ${ }^{7.8}$ Extended-spectrum beta-lactamase (ESBL) producing Enterobacteriaceae are an emerging group of drug resistant organisms responsible for UTI, specially, among patients with DM.,

MDR is defined as an organism having non-susceptibility to at least one agent from three groups of antimicrobials. ${ }^{8}$ UTI caused by single drug resistant organisms are common; UTI caused by extensively drug resistant (XDR) bacteria and pan drug resistant (PDR) bacteria are also reported. . $^{8,10,11}$ Besides the bacterial inherent and acquired mechanisms of developing drug resistance, easy availability of antimicrobials and drug dispensing without prescriptions by registered physicians, inadvertent and non-judicious use of antimicrobials, for example, use of antibiotics in non-specific febrile illnesses, are contributing to these increasing levels of drug resistance.
As UTI is a common clinical problem, preventive strategies may play a role in reducing disease burden, especially in high risk groups. Use of antibiotics in UTI is advisable depending upon local antibiotic sensitivity patterns and antibiotic stewardship programs may help combating drug resistance, not only for UTI, but also for other infections. It is appreciated that many older generations of antimicrobials are regaining their susceptibility to common microbial agents. Clinicians should be very much cautious before choosing and prescribing an antibiotic, while policy makers should make guidelines for common infections depending on local antibiotic sensitivity patterns (available from local microbiology laboratories). Good liaisons between clinicians and microbiologists may be a way to choose antimicrobial agents in UTI and other bacterial infections and help in reducing antibiotic resistance.

(J Bangladesh Coll Phys Surg 2021; 39: 76-77)

DOI: https://doi.org/10.3329/jbcps.v39i2.52386

\section{Dr. Muhammad Abdur Rahim}

Associate Professor, Department of Nephrology, BIRDEM General Hospital, Dhaka, Bangladesh. Email: muradrahim23@yahoo.com

\section{Prof. Brig. Gen. (Retd.) Mamun Mostafi}

Professor and Head, Department of Nephrology, Gonoshahthaya Samajvittik Medical College and Gonoshasthaya Nagar Hospital, Dhaka, Bangladesh. Email: mamunmostafi@yahoo.com

\section{References}

1. Stamm WE, Norrby SR. Urinary tract infections: disease panorama and challenges. $J$ Infect Dis 2001;183(Suppl 1):S1-4. https://doi.org/10.1086/318850 PMid:11171002

2. Ronald AR, Nicolle LE, Stamm E, Krieger J, Warren J, SchaefferA, et al. Urinary tract infection in adults: research priorities and strategies. Int $\mathrm{J}$ Antimicrob Agents 2001;17:343-8. https://doi.org/10.1016/ S09248579(00)00356-3, https://doi.org/10.1016/ S0924-8579 (01)00303-X 
3. Rahim M, Mitra P, Zaman S, Samad T, Ananna M, Hossain $M$, et al. Risk factors for urinary tract infection with extended spectrum beta lactamase producing uropathogens: single center experience from a developing country. Nephrology Dialysis Transplantation 2018; 33 (suppl_1): i388, https://doi.org/10.1093/ndt/gfy104.SP 132 https://doi.org/10.1093/ndt/gfy104.SP132

4. Ahammed F, Hossain ME, Hossaim MG, Karmakar G, Kabir MR, Chowdhury IA, et al. Clinical and bacteriological profile of UTI patients in Medicine Department in a teaching hospital of Bangladesh. J Bangladesh Coll Phys Surg 2021; 39(2): (in press)

5. Rahman R, Rahim MA, Afroze SR, Mitra P, Samad T, Tareqe A, et al. Pattern of Bacterial Pathogens Causing Urinary Tract Infection and Their Antibiotic Sensitivity: A Tertiary Care Hospital Experience. BIRDEM Med J 2016; 5(1): 20-3. https://doi.org/ 10.3329/birdem.v5i1.28369, https://doi.org/ 10.3329/ birdem.v5i1.28369

6. Warren JW, Abrutyn E, Hebel JR, Johnson JR, Schaeffer AJ, StammWE. Guidelines for antimicrobial treatment of uncomplicated acute bacterial cystitis and acute pyelonephritis in women. Infectious DiseasesSociety of America (IDSA). Clin Infect Dis 1999; 29:745-58. https://doi.org/10.1086/ 520427, PMid:10589881

7. Ramírez-Castillo FY, Moreno-Flores AC, AvelarGonzález FJ, Márquez-Díaz F, Harel J, Guerrero-Barrera AL. An evaluation of multidrugresistant Escherichia coli isolates in urinary tract infections from Aguascalientes, Mexico: crosssectional study. Ann Clin Microb Antimicrob
2018;17:34. https://doi.org/10.1186/s12941- 018-0286-5, PMid:30041652 PMCid:PMC6057003

8. Magiorakos A-P, Srinivasan A, Carey RB, Carmeli Y, Falagas ME, Giske CG, et al. Multidrug-resistant, extensively drug-resistant and pan drug-resistant bacteria: an international expert proposal for interim standard definitions for acquired resistance. C $1 \mathrm{i} \mathrm{n}$ Microbiol Infect 2012 Mar;18(3):268-81.doi: 10.1111/j.1469-0691.2011.03570.x. https://doi.org/ 10.1111/j.1469-0691.2011.03570.x, PMid:21793988

9. Iqbal S, Rahim MA, Samad T, Ananna M, Mitra P, Chowdhury T. Extended-Spectrum Beta-Lactamase Producing Escherichia coli and Klebsiella pneumoniae are Emerging as Major Pathogens Responsible for Urinary Tract Infection. Bangladesh Crit Care J 2015; 3(2): 49-52. https://doi.org/10.3329/ bccj.v3i2.25109, https://doi.org/10.3329/bccj.v3i2.25109

10. Bao J, Wu N, Zeng Y, Chen L, Li L, Yang L, et al. Non-active antibiotic and bacteriophage synergism to successfully treat recurrent urinary tract infection caused by extensively drug-resistant Klebsiella pneumonia. Emerging Microbes \& Infections 2020; 9(1):771-4. DOI: $10.1080 / 22221751.2020 .1747950$ https://doi.org/10.1080/22221751.2020.1747950 PMid:32212918 PMCid:PMC7170350

11. Falagas ME, Bliziotis IA, Kasiakou SK, Samonis G, Athanassopoulou P, Michalopoulos A. Outcome of infections due to pan drug-resistant (PDR) Gram-negative bacteria. BMC Infectious Diseases 2005;5: 24. https://doi.org/10.1186/1471-2334-5-24, PMid:15819983 PMCid:PMC1087841 